\title{
Promoting Changes in the Process of Acquiring the English Phonological Component
}

\author{
By María Susana Waasaf* \\ Nancy Leánez ${ }^{\dagger}$
}

\begin{abstract}
The purpose of this paper is to present the results obtained from a blended-learning pedagogic experience in the English Phonetics and Phonology classes, at Facultad de Filosofía Humanidades y Artes, Universidad Nacional de San Juan, Argentina. In this experience, interests related to the teaching at higher level education and the use of technological resources merge together. Two issues will be addressed: a) the use of the e-mail and the implementation of a social networking site, Facebook, both of them used for academic purposes; and $b$ ) the results of a survey which was administered to students so as to appraise their opinions about the usefulness of these assets. As university teachers, we are sensitive to the changes that our society is experiencing regarding information and communication technologies (ICTs). The incorporation of technological resources of the Web 2.0 to curricular units, somehow generates disruptions to traditional learning environments and opens up a range of possibilities which make it easier for students to build and process knowledge in different ways. The theoretical framework underlying this experience comes from the field of applied linguistics, particularly in the area concerning the acquisition of the phonological component of English as a foreign language. The methodology dimension of this didactic-technological proposal is based on the parameters of blended learning, which gives room for the application of technological tools which complement face-to-face learning. In this approach,synchronous learning (face-to-face) is complemented and enhanced by asynchronous learning through the use of computer technology. Both perspectives seem to be complementary in that they can promote educational change, facilitate the learning process, stimulate the students' motivation and, eventually, help them become more cognitively and metacognitively autonomous.
\end{abstract}

\footnotetext{
*Professor, Facultad de Filosofía, Humanidades y Artes, Universidad Nacional de San Juan, Argentina.

†Professor, Facultad de Filosofía, Humanidades y Artes, Universidad Nacional de San Juan, Argentina.
} 


\section{Introduction}

The breakdown of traditional scenarios and the introduction of new notions of space and time to the interior of learning situations in higher education, has put forward the challenge of building learning environments that exhibit different possibilities for generating knowledge and processing it. The use of Information and Communications Technology (ICT) requires the design of innovative methodologies that offer new ways to more up-to-date learning practices. As a result, a renewal of curricular designs is imposed to meet the demands of the target educational community that is becoming more knowledge-based and marked by a permanently increasing flow of information. As teachers of English Phonetics and Phonology at Facultad de Filosofía, Humanidades y Artes, Universidad Nacional de San Juan, Argentina, we envisioned the need for changes in order to enhance the acquisition of the English phonological component. Consequently, we have reframed the concepts underpinning our teaching practices so that they could become more theoretically informed and more appropriately contextualized.

Therefore, the purpose of this work is to demonstrate how a blendedlearning pedagogic experience was implemented in our classes. Two issues will be addressed: a) how the integration of two technological tools - e-mail and Facebook - was carried out, and b) the results obtained from a survey administered to students to appraise their opinions about the usefulness of these resources.

\section{Literature Review and Theoretical Perspectives}

The theoretical framework underpinning this experience comes from the field of Applied Linguistics, particularly from the area concerning second language acquisition, and more specifically, the acquisition of the phonological component.

The field of second language learning has been growing significantly and has expanded its scope to embrace diverse and sometimes dissimilar areas. The literature that analyses this issue is abundant and is rooted in Skinner's behaviourist approach which had great influence on language teaching back in the 60s. As time went by, new research changed this perspective. Thus, a cognitive school of psychology shifted the focus of attention from behaviourism to the mental processes involved in learning. Within this approach, at one extreme, was the constructivist movement (Piaget, 1966) which explained "the ways in which learners make their own personal sense of learning tasks, their environment, the teacher and the actual process of learning" (Williams \& Burden, 1997, p.29). Within this trend, a new perspective which viewed the person as a social being introduced the notions of interaction and social roles (Vygotsky, 1962). Its followers expanded, reviewed or elaborated on already existing concepts and brought in new dimensions which enhanced this domain. At the other extreme, were the information 
processing theories (Atkinson \& Shiffrin, 1968), which focused on the way in which information is taken in and processed. In doing so, they drew an analogy between the workings of the brain and a highly complex computer. One of these models, Adaptive Control of Thought, formulated by Anderson (1983), provided us with a suitable framework to carry out this piece of research. This proposal is a general cognitive model of skill acquisition which can be applied to those aspects of second language learning, that require proceduralization and automation. It assigns a central role to the fact that practice leads to automation, a tenet that is crucial to the acquisition of the English pronunciation. Anderson identifies three types of memory: a working memory, and two kinds of long-term memories, declarative -what we know about something- and procedural -what we know how to do. Both types of knowledge are stored differently. In Anderson's model, learning is incremental in nature. Once skills are proceduralized, they are performed automatically without having to resort to the working memory.

\section{Blended Learning: Brief Description of its Framework}

Due to the ubiquity of Internet, a growing number of studies have addressed and reflected upon the issue of integrating Web 2.0 tools in higher educational environments (Prensky, 2001; Blattner \& Fiori, 2009; Adell, 2004; Bartolomé, 2004; Salinas, 1999, among others). An analysis of the published material shows that there are different stances in the treatment of this topic. Even when different viewpoints are more evident if proposals on the Web are compared to in-print material, E-tools are increasingly being adopted in formal learning settings, with the purpose of building up communities of learners and encouraging collaborative work.

The theoretical-methodological concepts supporting the experience that we present in this article, have been drawn from the parameters of blended learning (b-learning), an approach which gives room for the integration of ICT work in the traditional face-to-face teaching environments (Sharma \& Barret, 2007). In this framework, synchronous learning is complemented and enhanced by asynchronous learning through the use of computer technology. Both perspectives seem to be complementary in that they can promote educational change, facilitate the learning process, stimulate the students' motivation and, eventually, help them become more cognitively and metacognitively autonomous.

Experts in the field adopted an eclectic position when they realized that not all theories of learning suited their particular conception of this process. According to Bartolomé (2004, p.11), "b-learning is not a learning model based on a general theory of learning but the application of an eclectic and practical thought" [our translation]. When working within this framework it is of vital importance to previously determine what the learning objectives are, what theories support this process and which technological resources are the most suitable. This author also expresses that "The key to methodological change is not to learn more (which, in fact, does not happen, as has been widely demonstrated) but to learn differently" (p.17) [our translation]. 
The scenario thus posed by the integration of ICT in the educational field means a break from the traditional educational paradigms. Consequently, it is necessary to redefine teachers and students roles since both are active agents of the educational process. In connection with this idea and according to the skill and dexterity with which people learn to use technological devices, Prensky (2001, p.1) refers, on the one hand, to "digital natives" as those who have an innate facility to intuitively manage these resources because "they have spent their entire lives surrounded by and using computers, videogames, digital music players, video cams, cell phones, and all the other toys and tools of the digital age". He goes on asserting that "today's students think and process information fundamentally differently from their predecessors" [italics in original text]. On the other hand, Prensky calls "digital immigrants" those who should make an effort to learn and incorporate the codes of the digital culture. Broadly speaking, most of the teachers form part of the last category, while the students belong to the first one, since they were born in this era, and grew up with technology. If we, teachers, want to reduce the intergenerational gap, we must develop the necessary skills to guide our students in the process of acquiring new knowledge in a flexible learning environment.

B-learning followers assert that students naturally develop digital skills as part of their learning process. Bartolomé (2004) mentions the following as significant:

- searching and finding relevant information on the net

- developing criteria to assess the importance of this information

- applying already acquired knowledge to building up new information

- working as a team to share and enlarge the knowledge domain

In the context of a b-learning experience, Salinas (1999) claims that teachers must also be capable of:

- guiding students in the academic use of technological resources

- promoting students self-directed learning in exploiting the possibilities of network as a system of access to learning resources

- organizing the learning environment in which students use these resources

- guiding learners in the development of collaborative experiences

- monitoring the students' progress by providing positive feedback

- offering learners opportunities for the communication of their work

In sum, and adopting Monereo's words (2009, p.5), "it appears clearly stated what a good teacher has to do: what cannot be done by a machine" [our translation]. 


\section{An Approach to Integrating Technology}

According to Mishra and Koehler (2006), the integration of technology requires developing a dynamic relationship between three primary forms of knowledge: Content (CK), Pedagogy (PK), and Technology (TK), hence, the name of their approach, Technological Pedagogical Content Knowledge (TPACK). Equally important to this model are the interactions between and among these bodies of knowledge (Figure 1).

Figure 1. Tpack-Technological Pedagogical Content Knowledge Framework

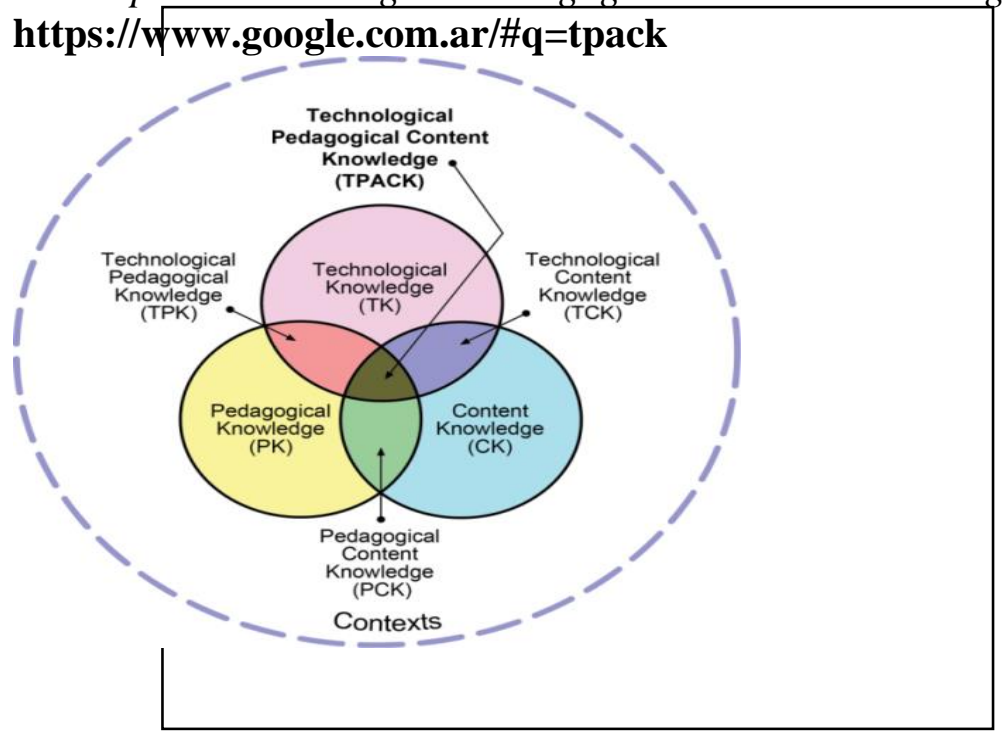

TPACK authors assumed this conceptual framework would not only be useful for embodying the proposal of integrating technologies in education, but also for transforming teacher education and professional practice. Their design addresses the complex, multifaceted and situated nature of teacher knowledge. In their opinion, teachers should be able to negotiate the interplay of these components for an effective integration of technology.

This, in turn, requires rearranging practices, reviewing and giving a new meaning to the pedagogical and disciplinary knowledge, in order to accommodate this new complex scenario.

\section{Methods}

\section{Participants}

This work describes a b-learning experience carried out with thirty second year students attending the subject English Phonetics and Phonology, at college level. The participants ranged in age from 19-30. The purpose of this experience was to continue with the integration of technology in our educational context with the intent of optimizing the process of acquisition of the English phonological component. 


\section{Design and Implementation of Digital Tools}

We chose two resources that have great social impact nowadays because they generate different channels of communication and interaction: e-mail and the social networking site, Facebook. Following basic b-learning tenets, these devices, are regarded as supplementary tools that complement traditional faceto face interactions. The design and implementation of these digital devices were organized according to two broad categories of use: 1) academicorganizational and 2) socio-affective. The first one is related to the way in which information is organized and distributed among the participants involved, i.e. how teacher-student, student-material and student-student interactions are promoted during the development of the subject (Hanna, 2000). The second category - socio-affective - refers to those aspects related to emotions and attitudes, and the way in which different interactions encourage a sense of togertherness and collaborative work.

E-mail

The integration of this tool opened up a more informal communicative channel between teachers and students. In this respect, Debard \& Guidara (1999) make reference to the importance of the frequent use of asynchronous communication in higher education so as to increase teacher-student contact. These authors point to e-mail as a tool which fosters students' interaction and leads to deeper, more active and more engaged learning in a collaborative atmosphere which is highly beneficial for the learning process.

E-mail offers a very fast way of exchanging digital messages through the Internet. Some of the pedagogical functions of this asynchronous resource include information distribution through file attachments of documents of various types (texts, illustrations, graphics, photographs, etc.), communication through various semiotic systems (writing, audio, video, etc.), record keeping, and content enrichment. E-mail can also be a powerful tool for delivering immediate feedback to students which will in turn increase the processing of new knowledge. Nevertheless, it is worth mentioning that successful use of email in any educational environment will depend upon how well the demands of the learners are met (Huett, 2004).

\section{Pedagogical Strategy}

In this section, an overview of the way in which e-mail was integrated in our educational context is provided. Firstly, and from the academicorganizational perspective, the interaction teacher-student was favoured. The teaching staff provided tutorial guidelines on the educational uses of this tool, either in class or through Facebook. Next, the gmail account englishphonetic sandphonology2@gmail.com was generated to send text files or attachments related to the declarative and procedural contents of the subject involved and to solve students' queries on specific issues related to the units of learning. Teachers also sent information via e-mail about class assignments and evaluation dates. Following the instructions given, students could clarify 
doubts, send text files and upload PowerPoint presentations in different formats.

It is interesting to note that students also resorted to other resources on the Web 2.0 to record audio files of selected texts read aloud using the site www.vocaroo.com. They attached a link or uploaded the file from their mobile phones to the subject e-mail address. Later, teachers sent corrective feedback to each student pointing out strengths and weaknesses in their oral production. This procedure allowed learners to become aware of their mistakes and, consequently, apply different repair strategies during the process of learning the phonological component. Figure 2 below illustrates a student-teacher exchange.

Figure 2. E-mail Files sent by a Student and a Teacher

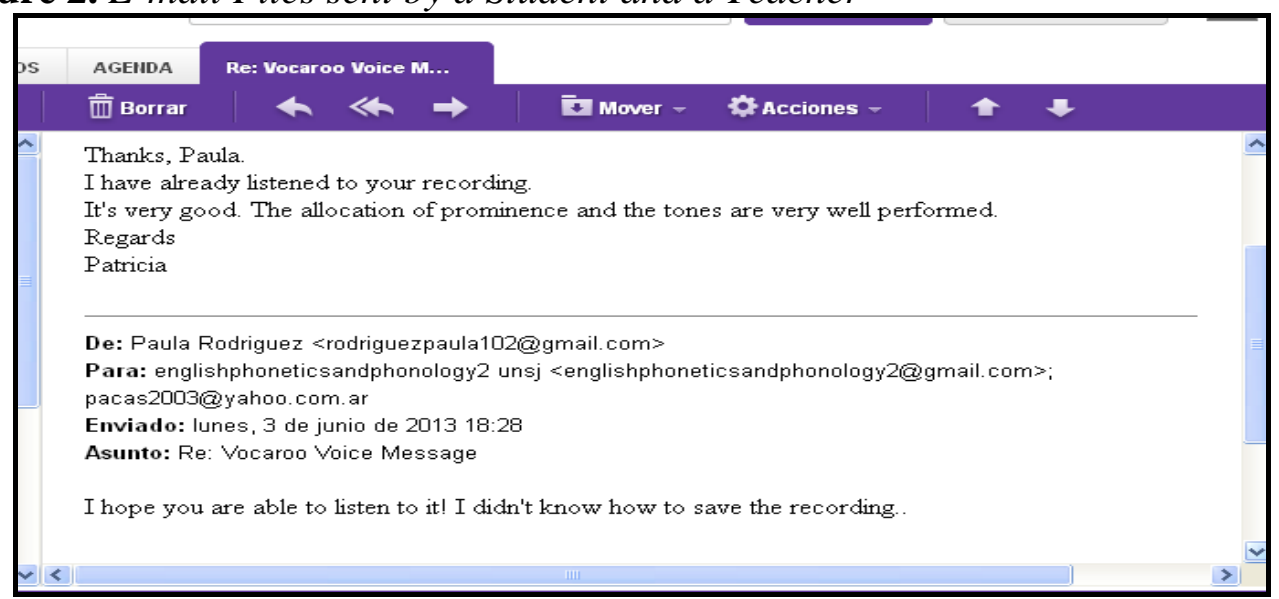

With regard to the student-material interaction, it was possible to observe that students resorted to the use of different cognitive strategies during the process of building up their knowledge. These strategies let them analyze, organize, elaborate and then present information in different formats, being permanently monitored and guided by teachers in the process. Now, in relation to the student-student interaction, most of the learners were in contact with their classmates to exchange ideas and opinions related to the proposed learning assignments. In this way, this technological resource facilitated online interaction and asynchronous collaborative work.

Concerning the socio-affective dimension, e-mail promoted new ways of interpersonal communication among teachers and learners. It helped create a sense of learning community, extending the space-time dimension of the classroom. Students' motivation was enhanced, collaborative learning was promoted and a more relaxed atmosphere was created. Students could actually perceive the teachers' presence, without being actually present.

Table 1 below summarizes the academic-organizational and socioaffective uses of e-mail in our educational context. 
Table 1. Educational uses of e-mail

\begin{tabular}{|c|c|c|}
\hline & E-mail uses & \\
\hline \multirow{4}{*}{ 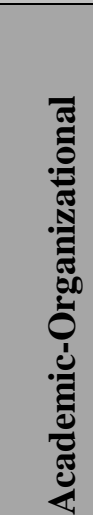 } & Messaging & $\begin{array}{l}\text { - Teacher-student communication } \\
\text { - Student-student interactions to share } \\
\text { comments }\end{array}$ \\
\hline & Text attachments & $\begin{array}{l}\text { - Course material } \\
\text { - Study guides } \\
\text { - Self-evaluations }\end{array}$ \\
\hline & Audio files & $\begin{array}{l}\text { - Audio and voice files using different } \\
\text { formats }\end{array}$ \\
\hline & Graphic information & $\begin{array}{l}\text { - Power-Point/Prezi presentations } \\
\text { - Content systematizations }\end{array}$ \\
\hline \multirow{2}{*}{ 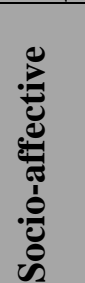 } & $\begin{array}{l}\text { Teacher-student/ student- } \\
\text { student interaction }\end{array}$ & $\begin{array}{l}\text { - Interpersonal communication } \\
\text { - Supporting interactions } \\
\text { - Sense of community } \\
\end{array}$ \\
\hline & Attitudes and emotions & $\begin{array}{l}\text { - New time-space dimension of the } \\
\text { classroom } \\
\text { - Less uncertainty feelings }\end{array}$ \\
\hline
\end{tabular}

So far we have explored some e-mail applications within the blendedlearning framework adopted. In spite of the fact that e-mail communication often means extra work for teachers and sometimes can be time consuming (Debard \& Guidara, 1999), it is clear that this tool offers many advantages as well: it provides more immediate communication between teachers and students, it creates a positive academic atmosphere extending learning opportunities and it fosters better teaching-learning circumstances. The fluid interaction between the protagonists of this experience facilitated students' gradual development of autonomy and self-regulation of their own cognitive processes.

\section{Facebook}

With the purpose of reducing the gap between digital natives and digital immigrants, the teaching team decided to design and implement another technological device more informal and less traditional than e-mail: the social networking site Facebook. With the implementation of this tool, the consolidation of a community of learning was strengthened.

Facebook is a synchronous tool which can also be used asynchronously, as in our particular situation. One of the reasons for its course integration was the powerful social impact it has: everyone knew what was going on inside the group and everyone could help one another in solving problems. Many of its characteristics make it suitable for educational pursuits: instant messaging, posting of videos and photos, downloadable applications, compatibility with other web browsers, among others. One of its most important features is its ease of use which, coupled with its permanent connectivity, make it possible to create a virtual social community made up of subjects which, in general, have common interests. Additionally, it increases both teacher-student and student- 
student interactions in the form of web-based communication and promotes twenty-first century literacies (Muñoz \& Towner, 2009).

\section{Pedagogical Strategy}

The first step in the process of implementation of this platform was to create the profile page English Phonetics and Phonology. This page was used to communicate with the students and to post class materials. Next, a closed group, specifically created for the course, was set up by the teacher team. Then, students were invited, either in a face-to-face classroom setting or via e-mail, to form part of it. In order to ensure that all students were given the opportunity to become a member of the group, instructions on how to access the group page were given. This profile site included the membership list, the wall and the toolbar which allowed the members to share posts, links, photos and videos, events and documents. The wall, a public writing place, is available on the front page application when the group page is opened. Most of the interactions took place on the wall on account of its ease of use.

Facebook was also organized according to the same two categories of use: 1) academic-organizational, and 2) socio-affective. From the first perspective, the interaction teacher-student was favoured in the initial stage of the process. This communication was materialized through publications on the wall making announcements, posting course material, reminding students of office hours dates and time and evaluation dates, as well as home assignments and study guides instructions. Teachers e-mailed students information on how to send an audio file using either the link www.vocaroo.com or the mobile phone. Once these files were analyzed, corrective feedback was provided via private messages. Figure 3 illustrates how the course material appeared on the wall.

Figure 3. Course Material posted on the Wall

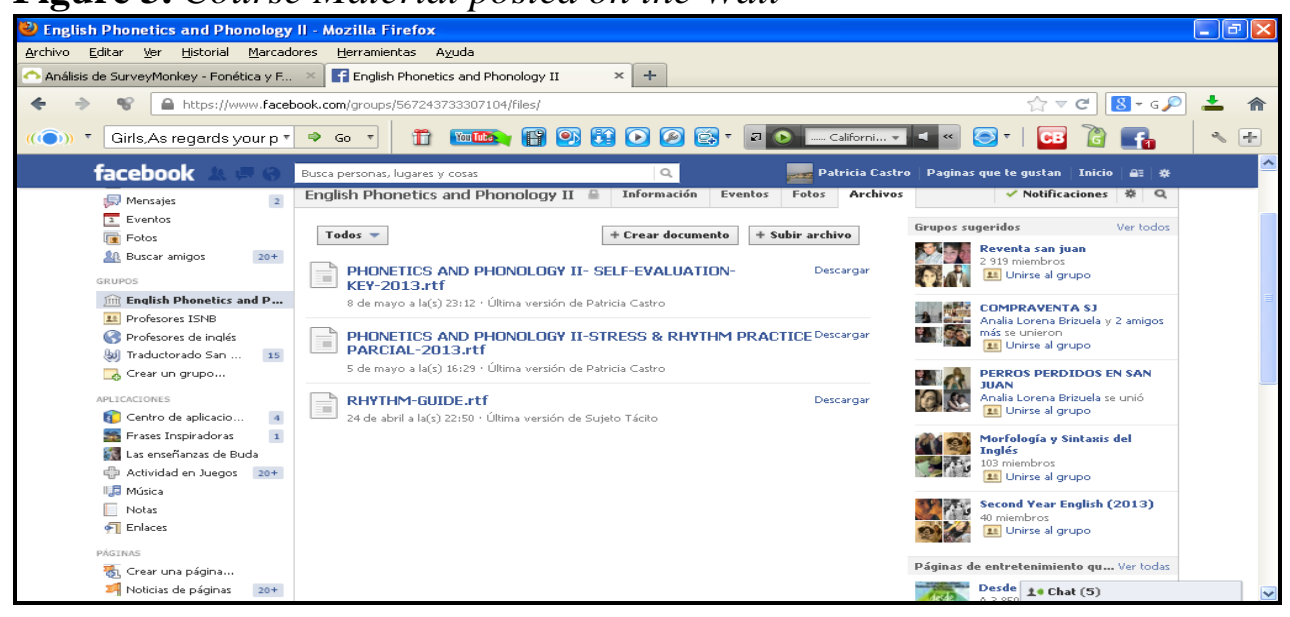


Figure 4.Video posted by a Student on the Wall

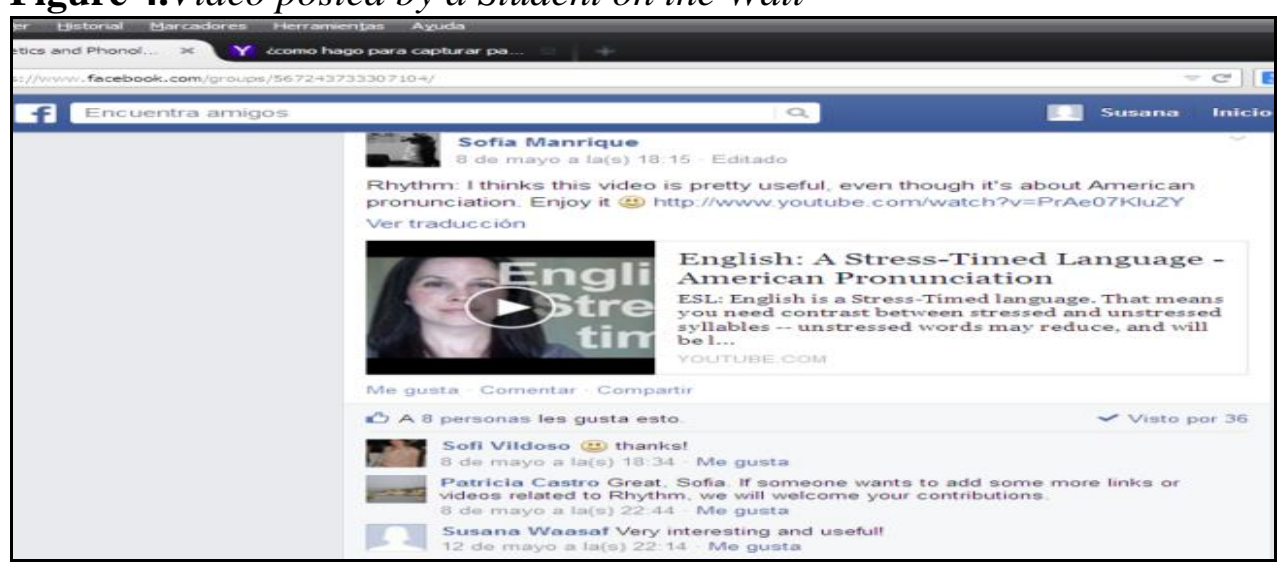

Facebook also contributed positively to the student-material relationship, since access to the course material posted on the wall as an attachment was immediate and easy. Additionally, learners could contact teachers directly on the wall posing any query about the attached information.

Regarding the socio-affective dimension, it was possible to note that the student-student relationship increased. Sometimes this connection overlapped with the teacher-student interactions, thus creating a particular virtual learning community which, in many cases, resembled the classroom scenario in real time. Even when the interactions were conducted sometimes synchronously and other times asynchronously, the students kept fluent communication with both teachers and peers. This situation contributed to increase collaboration among the members of the group, enhance their motivation, promote affective learning and create a positive classroom atmosphere where the participants received encouragement and support. Table 2 summarizes the academic use of Facebook in our subject.

Table 2. Educational uses of Facebook

\begin{tabular}{|c|c|c|}
\hline & \multicolumn{2}{|l|}{ Facebook uses } \\
\hline \multirow{3}{*}{ 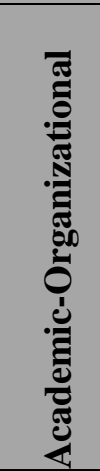 } & Messaging & $\begin{array}{l}\text { - Bidirectional private communication: teacher- } \\
\text { student and student-student } \\
\text { - Posting audio files }\end{array}$ \\
\hline & Wall & $\begin{array}{l}\text { - Multidirectional communication among all } \\
\text { - } \text { members } \\
\text { - } \text { Announcements } \\
\text { - Corre attachments } \\
\text { - Useful links }\end{array}$ \\
\hline & Events & - Remind students of upcoming events \\
\hline$\stackrel{0}{\Xi}$ & $\begin{array}{l}\text { Teacher-student/ } \\
\text { student-student } \\
\text { interactions }\end{array}$ & $\begin{array}{l}\text { - Synchonous/asynchronous interactions } \\
\text { - } \quad \text { Particular virtual learning community }\end{array}$ \\
\hline 車造 & $\begin{array}{l}\text { Attitudes and } \\
\text { emotions }\end{array}$ & $\begin{array}{l}\text { - More affective and collaborative communication } \\
\text { - Sense of belonging to a community }\end{array}$ \\
\hline
\end{tabular}


In this section, some educational uses of the social networking site Facebook have been addressed. Its integration in our particular context facilitated students' participation in the process of building up their phonological knowledge and increased their motivation and their sense of belonging. In spite of the fact that all the students signed up as members of the group, their participation varied. Nevertheless, the fluent interactions established among the members of the group created a favourable context which eventually resulted in improved learning conditions.

\section{Data Collection}

So as to measure the impact of the integration of these tools into the more traditional face-to-face teaching environment, an exploratory test was carried out. Data was collected through an opinion questionnaire which was administered to all the participants at the completion of the course. The instrument consisted of 9 items inquiring information on learners' ${ }^{\prime}$ attitudes and perceptions and benefits and limitations of using these tools. An additional open-ended item was included with the purpose of letting students communicate their personal points of view. It was posted on the www.surveymonkey.com page which allows only 10 questions. Students answered online using the link http://es.surveymonkey.com/s/35R6T77 which was posted on the Facebook page and was also sent via e-mail.

\section{Analysis and Findings}

Data obtained to describe the results of this experience provided us with basic insights and an initial impression of the outcomes. For the analysis, percentages were used to describe students' attitudes and perceptions and benefits and limitations. This preliminary information will be used for subsequent analysis phases of the research. Results obtained from the e-mail questions will be presented firstly. They will be followed by the results corresponding to the same questions for Facebook.

With respect to the use e-mail was put to, most of the students, $84 \%$, admitted to having made use of it to communicate with the teachers and a lower percentage, $64 \%$, expressed that they have also resorted to this tool to interact with classmates. As regards its frequency of use, student participation varied, $52 \%$ once a week and the rest only occasionally. When asked about the advantages of having integrated this resource, $86 \%$ of the students mentioned that it had contributed to strengthen their bonds with teachers and promoted collaborative learning. As to the potential benefits of using e-mail for educational purposes, the great majority, around $89 \%$, expressed that it helped them become more independent and responsible for their own learning. When asked to report on this experience, most of the students, 90\%, assessed it as positive and useful. Along similar lines, they added that they had felt comfortable with this tool.

When compared to the results obtained for e-mail, we may observe that the percentages for Facebook were, in general, higher. Thus, with reference to its use for communication with teachers and classmates, the percentages rose to 
$94 \%$ y $93 \%$, respectively. Likewise, its frequency of use was higher than for the other tool: more than half of the students, around $68 \%$, used this social network more than twice a week. As to its advantages, with reference to their bonds with teachers and collaborative learning, the percentage obtained, 88\%, was approximately the same as for the other tool. Students also acknowledged that it allowed them to be in close contact with their peers, share their academic work, cooperate with others and learn from one another. They also pointed out that the communication through this medium was fast and effective. As to its potential benefits, the great majority, around 93\%, expressed that this tool helped promote their active involvement in the learning process, and consequently, they became more autonomous. When asked to report on this experience, most of them, $96 \%$, assessed it as positive because it contributed to increase their confidence and motivation. They believed that technology facilitates online work and encourages more fluid communication among the members of the educational community.

Table 3 indicates the data described above.

Table 3. Comparison of Percentages obtained for both Tools

\begin{tabular}{|l|l|l|}
\hline & E-mail & Facebook \\
\hline Use & $\begin{array}{l}84 \% \text { with teachers } \\
64 \% \text { with partners }\end{array}$ & $\begin{array}{l}94 \% \text { with teachers } \\
93 \% \text { with partners }\end{array}$ \\
\hline Frequency of use & $\begin{array}{l}52 \% \text { twice a week } \\
\text { Rest: occasionally }\end{array}$ & $68 \%$ more than twice a week \\
\hline Advantages & $\begin{array}{l}86 \% \text { promoted interactions } \\
\text { and collaborative work }\end{array}$ & $\begin{array}{l}88 \% \text { promoted interactions and } \\
\text { collaborative work }\end{array}$ \\
\hline Benefits & $\begin{array}{l}89 \% \text { more independent and } \\
\text { responsible }\end{array}$ & $\begin{array}{l}93 \% \text { more active and } \\
\text { autonomous participants }\end{array}$ \\
\hline $\begin{array}{l}\text { Personal } \\
\text { evaluation }\end{array}$ & $\begin{array}{l}90 \% \text { positive and useful } \\
\text { experience }\end{array}$ & $\begin{array}{l}\text { It enhanced motivation and } \\
\text { conficence }\end{array}$ \\
\hline
\end{tabular}

Concerning the learners' appreciation of the integration of these tools, most of the students recognized them as being complementary and valued them for their accessibility and immediacy. They had positive opinions about the experience and admitted it helped them become more independent and responsible. The following respondents' comments are cited as they were expressed:

“...these tools help us to be informed and aware of assessment and home assignment dates..."

"... they solve the problem of conflicting time-tables..."

Additionally, the students perceived the usefulness of both resources to promote the learning of the English pronunciation. One of them stated: 
“...I really like the methodology used. Technological resources help not only to improve the process of learning pronunciation, but also to save class time to practise pronunciation through face-to-face collaborative work..."

It is also important to notice that learners did not disregard the teachers' role as mediators in the process of constructing new knowledge:

"Though technology helps to facilitate physically independent work and supports a variety of communicative interactions, we also value the teachers' role as facilitators of pronunciation learning..."

Learners also seemed to be aware of the socio-culturally constructed nature of the learning process. The comments revealed that students felt at ease when working collaboratively in this new form of community.

\section{Conclusion}

This paper is the result of an exploratory search in which the issue of integrating technological tools in our English Phonetics and Phonology courses has been addressed. Within the framework of blended-learning, we have reflected not only on the challenges posed by the use of new technologies but also on the importance of the new forms of interaction generated in the 2.0 learning environment. This experience involved complex adjustments, where synchronous and asynchronous communications co-existed and contributed to the configuration of a new pedagogical scenario.

The use of e-mail, a more formal tool, was complemented by Facebook, which is more social and informal in nature. Both devices showed high percentages of use and promoted students' active involvement in the learning process. Most of them acknowledged the benefits of this experience because it strengthened the bonds between teachers and students helping to create favourable conditions for sharing academic work. Our results indicate that both devices appear to be potential pedagogic resources that contribute to optimizing the teaching-learning process. These tools enhanced students motivation, developed collaborative work and, consequently, helped learners become more cognitively autonomous. As a result, the classroom became a more open, flexible and interactive space where routines harmoniously coexisted with innovation and creativity.

The experience here presented intends to promote some kind of reflection on what is being done in our educational situation. This proposal means a step forward towards educational change in a clearly defined target community. It provides a starting point for further empirical research in the pedagogical uses of digital tools in the particular field of the acquisition of the phonological component of a foreign language. 


\section{Bibliography}

Adell, J., 2004. Internet en educación. Comunicación y Pedagogía, [online] Available at: < http://goo.gl/HmnVRm> [Accessed 2 April 2013].

Anderson, J. R., 1983. The architecture of cognition. Cambridge, Mass: Harvard University Press.

Atkinson, R. C. \& Shiffrin, R.M., 1968. "Human memory: a proposed system and its control processes". In: W.K. Spence and J.T. Spence, eds. 1972. The Psychology of Learning and Motivation: advances in research and theory. New York: Academic Press. pp. 89-195.

Bartolomé, A., 2004. Blended Learning. Conceptos básicos. Píxel-Bit. Revista de Medios y Educación, [online] Available at: <http://dialnet.unirioja.es/servlet/arti culo?codigo $=892487>$ [Accessed 21 August 2012].

Blattner, G. \& Fiori, M., 2009. Facebook in the Language Classroom: Promises and Possibilities. International Journal of Instructional Technology and Distance Learning, [online] Available at: 〈http://www.itdl.org/journal/jan09/article02. htm >

Debard, R. \& Guidara, S., 1999. Adapting asynchronous communication to meet the seven principles of effective teaching. Journal of Educational Technology Systems, [online] Available at: <http://baywood.metapress.com/app/home/contri bution.asp?referrer=parent\&backto=issue, 3,8;journal,59,169; linkingpublicationre sults,1:300322,1> [Accessed 16 June 2011].

Hanna, D., 2000. Higher Education in an Era of Digital Competition. Madison WI: Atwood Publishing.

Huett, J., 2004. Email as an Educational Feedback Tool: Relative Advantages and Implementation Guidelines, [online] Available at: <http://www.itdl.org/journal /jun_04/article06.htm> [Accessed 18 July 2011].

Mishra, P. \& Koehler, M., 2006. Technological Pedagogical Content Knowledge: A Framework for Teacher Knowledge, [online] Available at: <http://punya.educ. msu.edu/publications/journal articles/mishra-koehler-tcr2006.pdf $>$ [Accessed 15 May 2013].

Monereo, C., 2009. Competencia digital: Para qué, quién, dónde y cómo debe enseñarse. REVISTA AULA. De Innovacción educativa. 181, p. 5.

Muñoz, C. \& Towner, T., 2009. Opening Facebook: How to Use Facebook in the College Classroom. In: Society for Information Technology and Teacher Education Conference. Charleston, South Carolina, Mar 02, 2009. Chesapeake, VA: AACE.

Piaget, J., 1966. The Origins of Intelligence in Children. New York: International Universities Press.

Prensky, M., 2001. Digital Natives, Digital Immigrants. On the Horizon, [online] Available at: <http://www.marcprensky.com/writing/Prensky\%20-\%20Digital\% 20Natives,\%20Digital\%20Immigrants\%20-\%20Part1.pdf> [Accessed 19 May 2010].

Salinas, J., 1999. Rol del profesorado universitario ante los cambios de la era digital. Perfeccionamiento Integral del Profesor Universitario. In: Primer Encuentro Iberoamericano. Caracas, Venezuela, July 21-23, 1999. Caracas: Universidad Central de Venezuela.

Sharma, P. \& Barret, B., 2007. Blended learning: Using technology in and beyond the classroom. Oxford: Macmillan.

Vygotsky, L., 1962. Thought and Language. Cambridge, Mass: MIT Press.

Williams, M. \& Burden, R., 1997. Psychology for Language Teachers: a Social Constructivist Approach. Cambridge: CUP. 